\title{
СИНДРОМ ЕМОЦІЙНОГО ВИГОРАННЯ СЕРЕД МЕДИЧНИХ ПРАЦІВНИКІВ
}

\author{
T. B. Koca \\ Комунальна установа «Територіальне медичне об’єднання «Обласний иентр \\ екстреної медичної допомоги та медицини катастроф» Запорізької обласної ради \\ Тернопільський національний медичний університет \\ імені І. Я. Горбачевського МОЗ України
}

У статті проаналізовано проблеми емоційного вигорання серед медичних працівників. Для повсякденної діяльності медичних працівників характерним є високий рівень стресу, який вони відчувають доволі часто. Актуальність проблеми емоційного вигорання видно з наукових публікацій і досліджень, які значно зросли за останнє десятиріччя.

\section{BURNOUT SYNDROME AMONG MEDICAL CARE PROFESSIONALS}

\author{
T. V. Kosa \\ Municipal Institution of Zaporizhzhia Region Council "Territorial Medical Association \\ "Zaporizhzhia Regional Emergency and Disaster Medicine Center" \\ I. Horbachevsky Ternopil National Medical University
}

\begin{abstract}
The article deals with the issues of burnout syndrome among medical care professionals whose day-to-day activities are often accompanied by high-level stress situations. The fact that the number of researchers who addressed this topic has significantly increased over the last decade, proves its relevance and urgency.
\end{abstract}

Вступ. Всесвітня організація охорони здоров'я (ВООЗ) визнала, що синдром емоційного вигорання $\epsilon$ проблемою, що потребує медичної уваги. Згідно з визначенням ВОО3, «синдром вигорання (burnout syndrome) - це фізичне, емоційне або мотиваційне виснаження, що характеризується порушенням продуктивності в роботі та втомою, безсонням, підвищеною схильністю до соматичних захворювань, а також вживанням алкоголю або інших психоактивних речовин із метою одержати тимчасове полегшення, що має тенденцію до розвитку фізіологічної залежності та (у багатьох випадках) суїцидальної поведінки. Цей синдром звичайно розцінюється як стрес-реакція у відповідь на безжалісні виробничі та емоційні вимоги, що відбуваються через надмірну відданість людини своїй роботі з супутньою цьому зневагою до сімейного життя або відпочинку».

Основна частина. При сучасному навантаженні медичних працівників і введенні в їх роботу нових програм і підходів проблемою $\epsilon$ не те, що працівник емоційно вигорає, оскільки це є природний про-

C) T. B. Koca, 2019 цес. Проблема полягає в тому, що він не вміє це вчасно помічати. Тому $є$ дуже важливим визначення психодіагностичних прийомів оцінки рівня емоційного вигорання.

Відомий вислів: «Світячи іншим, згораю сам», приписують голландському лікарю XVII ст. Ніколасу ван Тульпу, який запропонував зробити його девізом лікарів, а символом - палаючу свічку.

Вважають, що термін «професійне вигорання» у науковий обіг увів американський психіатр Х. Дж. Фрейденбергер [1] для позначення психічного стану здорових людей, які постійно перебувають в емоційно перенавантаженій атмосфері, оскільки їхня професійна діяльність вимагає інтенсивного спілкування 3 людьми. Цей стан він назвав «burnout» (вигорання).

Цю проблематику досліджували зарубіжні та вітчизняні психологи, а саме: М. Буриш, Г. Діон, К. Маслач, С. Джексон, Г. Сельє, В. Бойко, Н. Водоп'янова, Г. Ложкін, Н. Левицька, Л. Карамушка, Т. Зайчикова, В. Орел, Т. Форманюк, С. Максименко [1].

Причиною професійного вигорання у медичних закладах $є$ емпатія - співпереживання емоційному 
стану пацієнта. Медичний працівник сприймає проблеми пацієнта як власні. Оскільки медична діяльність пов'язана зі здоров'ям людини, не маючи достатнього досвіду і практичних навичок, медичний працівник особливо гостро переживає за наслідки професійної діяльності. Причинами професійного вигорання також $є$ напружені стосунки в колективі, з начальством; недостатнє матеріальне заохочення медичного працівника; надмірна завантаженість; погані умови роботи; невідповідність між бажаним і рівнями відповідальності; неможливість особистого розвитку.

Емоційне виснаження проявляється психічною втомою, емоційним спустошенням, симптомами депресії. Спочатку спостерігають емоційне перенасичення, що супроводжується емоційними зривами, агресивними реакціями, спалахами гніву. Потім розвивається емоційне виснаження, втрачається інтерес до навколишньої реальності [2].

Деперсоналізація - знецінення (дегуманізація) міжособистісних стосунків, негативізм, цинічне ставлення до почуттів та переживань інших людей. Починають проявлятися негативні установки, зростає знеособлення та формальність контактів, виникають спалахи роздратування та конфліктні ситуації. Для всіх характеристик деперсоналізації важлива втрата емоційного компонента психічних процесів (втрата почуттів до близьких людей, зниження емпатії - чуйності, співпереживання) [2].

Редукція особистісних досягнень характеризується зниженням професійної ефективності працівника, що може проявлятися в негативізмі щодо службових можливостей, в обмеженні обов'язків до соціального оточення, у зниженні відчуття значущості діяльності, що виконується. Яскраво виражене почуття власної неспроможності та некомпетентності. Наявність цих складових спричиняє професійну деформацію особистості, зниження якості життя і втрату сенсу існування [3].

У зв'язку з цим, синдром емоційного вигорання розглядається деякими авторами як «професійне вигорання», що зумовлює вивчення цього феномена в аспекті професійної діяльності. Вважають, що такий синдром найбільш характерний для представників соціальних або комунікативних професій системи «людина - людина». Серед основних професійних чинників, що зумовлюють результати дії тривалого стресу, можна виділити значне емоційне насичення актів взаємодії з пацієнтами. Серед медичних спеціальностей є ряд галузей з більш високим ри- зиком цього прояву. До них належать психіатрія, наркологія, екстрена медична допомога та інші галузі медицини, де нерідко доводиться мати справу з агресивною поведінкою пацієнтів, часто контактувати 3 психоактивно залежними особами. Робота з людьми похилого віку, хронічно і смертельно хворими, які потребують постійного інтенсивного догляду, та новонародженими також пов'язана з підвищеним ризиком вигорання. Зважаючи на значне навантаження, особливо за кількістю пацієнтів, з якими працюють медсестри і лікарі, виявлено, що синдром вигорання проявляється неадекватним реагуванням на пацієнтів і колег, відсутністю емоційного залучення, втратою здатності до співпереживання пацієнтам, перевтомою, яка призводить до редукції професійних обов'язків та негативного впливу роботи на особисте життя.

Синдром професійного вигорання у лікарів проявляється в зниженні зацікавленості в роботі, збільшенні витрати часу на встановлення діагнозу. Професійно втомлені лікарі можуть встановити неправильний діагноз, призначати неправильні методи лікування, затримуватися довше на роботі або ж раніше йти додому. У колективі це проявляється відособленістю від колег. З'являються шкідливі звички, що може мати погані наслідки не лише для медичного працівника, але і всього медичного закладу, оскільки він має доступ до різних лікарських засобів.

Висновки. Важливе значення має соціальний клімат у колективі, справедливе ставлення керівників до своїх колег, справедливий розподіл навантаження, створення сприятливих гендерних умов праці, особливо в умовах роботи із комп'ютерною технікою та інформаційними технологіями. Середпрофілактичних заходів потрібно:

- корегувати навантаження працівників;

- створювати сприятливі режими роботи (гнучкий та дистанційний);

- для деяких працівників змінювати професію і надавати допомогу в засвоєнні нових знань і умінь;

- створювати умови для підвищення кваліфікації;

- надавати можливість брати участь у науковопрактичних конференціях, круглих столах, нарадах;

- сприяти наданню лікарської допомоги.

Робота повинна приносити задоволення, а не бути тягарем. Потрібно створити такі взаємини в колективі, щоб кваліфіковані та досвідчені медичні працівники навчали молодих, і в усьому підтримували їх на початковому етапі роботи. Без взаємної поваги 
і дружніх стосунків нічого не вийде. Багато тут залежить від корпоративної культури, навчання і розвитку співробітників.

Краще всього організувати курси і тренінги безпосередньо на базі медичного закладу. Це зміцнить

\section{СПИСОК ЛІТЕРАТУРИ}

1. Бойко В. В. Энергия эмоций в общении: взгляд на себя и на других / В. В. Бойко. - М. : Наука, 1996. - 154 с.

2. Водопьянова Н. Е. Синдром выгорания: диагностика и профилактика / Н. Е. Водопьянова. - СПб. : Питер, 2008. - 336 c. стосунки в колективі, надасть працівнику почуття приналежності до медичного закладу.

Набагато ефективніше навчати працівників, які, відчуваючи добре ставлення і приналежність саме до цього медичного закладу, будуть працювати і не залишать його навіть у складні часи [3].

3. Знакова Т. А. Професійне «вигорання» керівників / Т. А. Знакова, А. С. Огнев // Управління персоналом. 2003. - № 11. - C. 64-75.

Отримано 30.09.19 